Arch. Tierz., Dummerstorf 46 (2003) 3, 285-292

Kaposvár University, Faculty of Animal Science, Hungary

GABRIELLA ANDRÁSSY-BAKA, RÓBERT ROMVÁRI, ZOLTÁN SÜTŐ, ANDRÁS SZABÓ and PETER HORN

\title{
Comparative study of the body composition of different turkey genotypes by means of CT (short communication)
}

\begin{abstract}
Male and female BUT Big 6 and Bronze turkeys (type 1967) kept in a gene reserve were in vivo investigated with non-invasive high resolution computerized tomography by means of a sipral CT scanner. The imaging procedure was carried out at the ages of 5, 12, 16 and 21 weeks on two turkeys, in both sexes. All animals were kept under intensive conditions according to the demands of the conformation and the body weight of the relevant group average. On the basis of 30-50 scans gathered from each bird during the scanning procedure the volumetric measurement of the total body muscle content was performed. These values were at the $5^{\text {th }}$ week 0.9 and 0.8 vs. 0.3 and $0.2 \mathrm{dm}^{3}$ in BUT male and female vs. Bronze male and female birds. At the $21^{\text {st }}$ week the respective values were: 12.65 and 7.66 vs. 3.60 and $2.28 \mathrm{dm}^{3}$. The total body fat content was characterised by the so called „fat index”, a value independent of the live weight. This indices were at the $21^{\text {st }}$ week: 0.12 and 0.20 vs. 0.12 and 0.13 following the above order. The investigation of the tissue development in the body was carried out by means of 3D histograms. The morphologic properties of the breast muscles were compared based on real $3 \mathrm{D}$ reconstructed images at the age of 21 weeks where the major differences concerned the $\mathrm{m}$. pectoralis superficialis. The applied imaging methods are well applicable to describe the anatomic and body compositional differences in the excessively different genotypes.
\end{abstract}

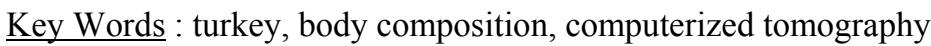

\section{Zusammenfassung}

Titel der Arbeit:Vergleichende Untersuchung der Körperzusammensetzung unterschiedlicher Putentypen mit Hilfe von CT (Kurzmitteilung)

Männliche und weibliche Puten unterschiedlichen Typs, BUT Big 6 und in Genreserve gehaltene Bronzeputen (Typ 1967), wurden in vivo nicht invasiv mit Spiral CT tomographiert. Die Aufnahmen wurden im Alter von 5, 12, 16 und 21 Wochen durchgeführt. Alle Tiere wurden in Intensivhaltung unter gleichen Bedingungen gehalten und entsprachen in Lebendmasse und Konformation dem entsprechenden Gruppendurchschnitt. Auf der Basis von 30-50 Querschnittbildern wurde die Gesamtfleischmenge des Ganzkörpers volumetrisch bestimmt. Im Alter von 5 Wochen betrug das Fleischvolumen im Ganzkörper 0,9 und $0,8 \mathrm{dm}^{3}$ bei BUT und 0,3 und 0,2 bei männlichen bzw. weiblichen Bronzeputen. Im Alter von 21 Wochen betrug das Fleischvolumen 12,65 und 7,66 $\mathrm{dm}^{3}$ und 3,60 und 2,28 $\mathrm{dm}^{3}$, entsprechend der Typen und Geschlechter. Das Gesamtfett im Ganzkörper wurde mit Hilfe des „Fett Indexes” charakterisiert um die Effekte der großen absoluten Lebendmassedifferenzen auszuschalten. Im Alter von 21 Wochen betrugen die Fett Indices: BUT Big 6 0,12 und 0,20 für männliche bzw. 0,12 und 0,13 für weibliche Bronzeputen. Die Entwicklung verschiedener Gewebetypen im Körper wurde mit 3D Histogrammen ermittelt und dargestellt. Morphologische Eigenschaften des Brustmuskels wurden auf der Basis einer 3D Rekonstruktion verglichen, wobei der M. Pectoralis superficialis der dominierende Muskel war. Die verwendeten Methoden sind gut geeignet um anatomische Differenzen und Unterschiede in der Körperzusammensetzung von sehr unterschiedlichen Putentypen zu beschreiben.

Schlüsselwörter: Puten, Körperzusammensetzung, Computer Tomographie

\section{Introduction}

Turkey is one of the domestic species where selection for meat production proved to be of very high efficacy. Based on data from performance tests between years 1973 
and 2000 the growth capacity of 16 -week-old turkeys improved by 75 percent in both sexes. In females and males raised until the $20^{\text {th }}$ week the live weight can reach 72 and 74 percent higher values than in 1973 (SÜTÖ et al., 2001).

The selection procedure for early growth rate resulted in measurably higher slaughter weights, the breast muscle weight intensely exceeds that of the thighs (HAVENSTEIN et al., 1988). This caused proportional changes in the total body and also in the anatomical properties of the different body regions in the turkey. However, not only meat production capacity but the fat deposition also increased strongly. NESTOR (1982) selected turkeys for high body weight gain in 14 generations and found that fat deposition was doubled at 16 weeks of age. The fat deposition was three times higher in females compared to males.

The in vivo CT imaging procedure applied in the current study was also used by BENTSEN and SEHESTED (1989), SVIHUS and KATLE (1993), and ROMVÁRI et al. (1994) for the determination of the abdominal fat amount and the breast muscle weight of broiler chickens. Body composition analysis of growing broiler chickens were performed by means of dual X-ray absorptiometry by (MITCHELL et al., 1997). MITCHELL et al (1991) applied MR imaging for the estimation of turkey breast muscles; similar investigations were carried out by KÖVÉR et al. (1997) on broilers. MRI and three dimensional reconstruction were used to estimate the volume and shape of the pectoralis muscle of chickens (SCOLLAN et al., 1998). The comparative investigation of the breast muscles of different broiler genotypes was performed by means of high resolution CT imaging by ROMVÁRI et al. (2000).

\section{Materials and methods}

CT scanning was performed in a repeated manner at the age of 5, 12,16 and 21 weeks on BUT Big 6 genotype turkeys possessing high early growth capacity, and on Bronze turkeys, a genotype autochthonous in Hungary, without the disadvantageous consequences of selection for meat production. Two turkeys form both sexes were investigated. Birds were raised in a closed, air-conditioned building on deep litter at the Test Station of the Kaposvár University, Faculty of Animal Science. The raising was based on a modern, intensive feeding serial.

The CT scanning was carried out at the Institute of Diagnostic Imaging and Radiation Therapy, on a Siemens Somatom S40 apparatus. Birds were scanned in a prone position, with stretched legs during anesthesia with $10 \mathrm{mg} /$ body weight $\mathrm{kg}$ Ketamine. Depending on the body size 30-50 cross-sectional consecutive scans of $10 \mathrm{~mm}$ slice thickness were taken from the total body. At the age of 21 weeks from the breast region $3 \mathrm{~mm}$ scans were also taken, with the special aim of the $3 \mathrm{D}$ reconstruction.

The image processing was double aimed. The determination of the total body composition was performed on the basis of the Hounsfield (HU) scale. According to this the muscle $(20-200 \mathrm{HU})$ and the fat $(-10-(-200) \mathrm{HU})$ density pixels were computed from all images. Afterwards, the volume of the different tissue types was determined, by taking the slice thickness and the zoom factor into account. Changes in the total body fat content were expressed by the fat index, which is independent of the body size. This index represents the ratio between the pixels falling into the fat density interval (from HU -200 to -10) and the total pixel number (ROMVÁRI, 1996).

Fifteen scans representing identical anatomic points were used for the graphical demonstration of the body composition from the birds in all age categories. Forty, so 
called Hounsfield variables (HUv) were calculated from the frequency values of the pixels; applying this variables 3D histograms were plotted to indicate the fat and muscle tissue development inside the body. The real geometric shape of the breast muscle was reconstructed in 3D at the age of 21 weeks (Able 3D Doctor 2.0 software).

\section{Results and discussion}

Data obtained in the present investigation are interpreted as tendencies due to the relative low number of animals examined. However, the importance of the results is based on the fact that those are collected from the identical birds during their growth, and represent the changes of the total body composition. The Table shows the live weight and muscle volume of the turkeys in all age categories investigated.

Table

Changes in the muscle volume $\left(\mathrm{dm}^{3}\right)$ and live weight $(\mathrm{kg})$ of the turkeys at $5,12,16$, and 21 weeks of age

\begin{tabular}{|c|c|c|c|c|c|c|c|c|}
\hline \multirow[t]{2}{*}{ Genotype } & \multicolumn{2}{|c|}{$5^{\text {th }}$ week } & \multicolumn{2}{|c|}{$12^{\text {th }}$ week } & \multicolumn{2}{|c|}{$16^{\text {th }}$ week } & \multicolumn{2}{|c|}{$21^{\text {st }}$ week } \\
\hline & $\begin{array}{c}\text { Live } \\
\text { weight }\end{array}$ & $\begin{array}{l}\text { Muscle } \\
\text { volume }\end{array}$ & $\begin{array}{c}\text { Live } \\
\text { weight }\end{array}$ & $\begin{array}{l}\text { Muscle } \\
\text { volume }\end{array}$ & $\begin{array}{c}\text { Live } \\
\text { weight }\end{array}$ & $\begin{array}{l}\text { Muscle } \\
\text { volume }\end{array}$ & $\begin{array}{c}\text { Live } \\
\text { weight }\end{array}$ & $\begin{array}{l}\text { Muscle } \\
\text { volume }\end{array}$ \\
\hline \multicolumn{9}{|l|}{ BUT } \\
\hline Male & 1.64 & 0.92 & 10.35 & 6.58 & 14.6 & 9.18 & 20.25 & 12.65 \\
\hline Female & 1.40 & 0.86 & 0.74 & 4.44 & 10.05 & 6.23 & 13.35 & 7.66 \\
\hline \multicolumn{9}{|l|}{ Bronze } \\
\hline Male & 0.80 & 0.37 & 3.62 & 1.91 & 4.82 & 2.61 & 6.85 & 3.60 \\
\hline Female & 0.61 & 0.29 & 2.44 & 1.39 & 3.17 & 1.78 & 4.0 & 2.28 \\
\hline
\end{tabular}

Data show a decreasing tendency of the muscle growth by the increase of the age in both genotypes. There is an expressed advantage of the modern genotype until the age of 12 weeks, due to the selection for early growth. As there were great and with the aging further increasing differences in the live weight of the genotypes "fat index" values were calculated at all analyzed age categories, which are depicted in Figures 1 and 2.

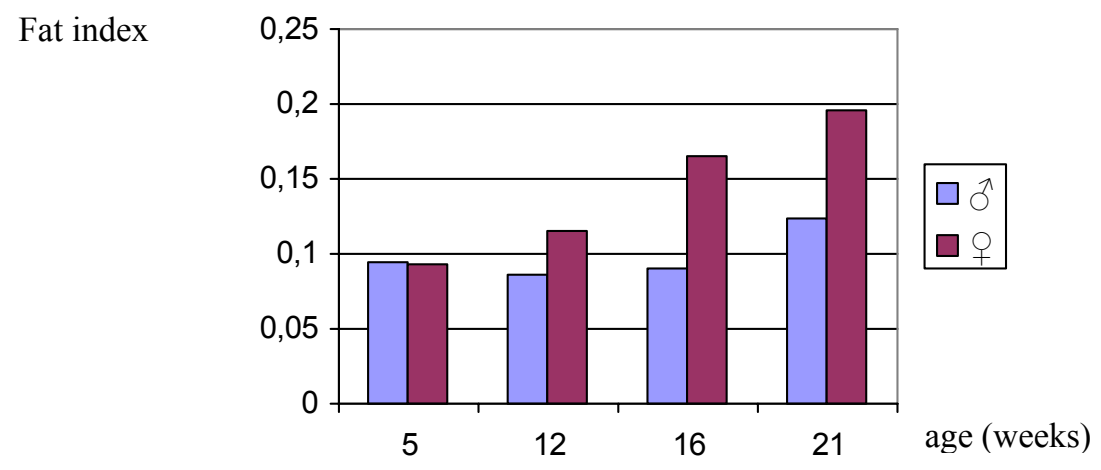

Fig. 1: Changes in the body fat index of the BUT turkeys

There is a clear difference between the two sexes in Figure 1, showing further increase by age. In males the body fat content does not alter largely until the age of 16 weeks, however, after that it intensely increases. The alteration of the fat index in males is a continuous process, reaching a nearly double value throughout the trial period.

Differences between sexes are less pronounced in the Bronze turkeys of slower growth (Fig. 2). However, the tendency of increasing fat deposition mainly after the $12^{\mathrm{th}}$ week is also clearly to be seen in this genotype. In the first part of the raising period of both genotypes the fat index values show general similarity in both sexes. After this period 
the differences increase, the highest value was shown in the female BUT turkey (Fat index $=0.2$ ). The total amount of the fat content can be ranked after that as follows: Bronze turkey female, BUT male and Bronze turkey male.

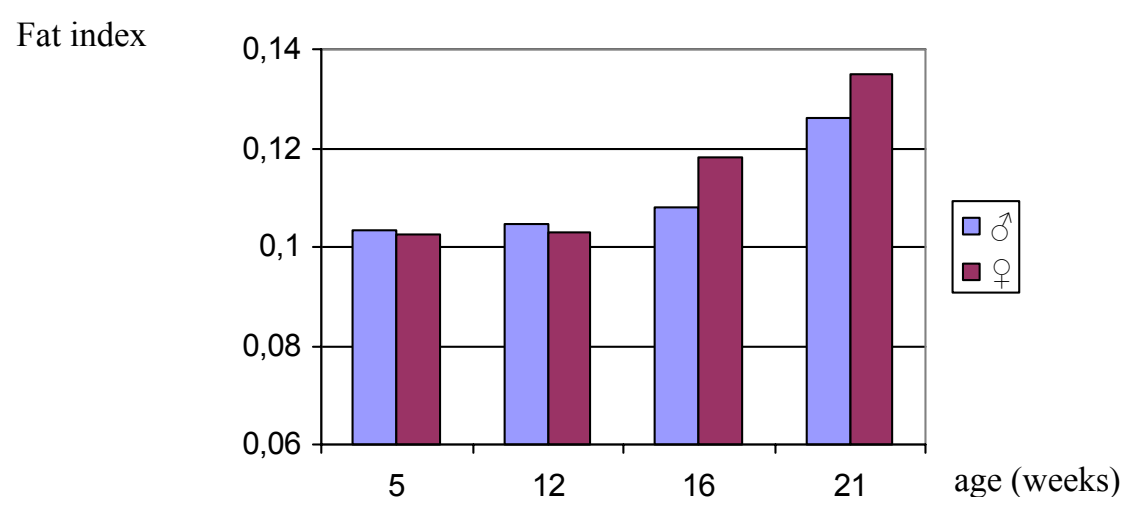

Fig. 2: Changes in the body fat index of the Bronze Turkeys

Changes described above concerned the total body, however, the following description is located to defined anatomic regions of the body. As the scan number covering the total body increased with the age, $15 \mathrm{CT}$ scans at well recognizable pre-defined anatomic locations were chosen, to assess a reliable basis for the comparison. Accordingly, the $6^{\text {th }}$ scan is located at the top of the clavicula (hypocleideum), the $11^{\text {th }}$ crosses the caudal end of the sternum.

The 3D histograms were plotted with the negative exponential interpolation method. The serial number of the cross sectional scans is marked on the on X-axis, the HU variables on the $\mathrm{Y}$-axis (numbering from 1 to 40, after reducing by 5 from -200 to +200 ) and the frequency of density values was illustrated on the Z-axis. For the proper comparison of the sexes in one genotype the scale of all three axes is always identical; however, due to the great differences of the genotypes in those this was not possible.
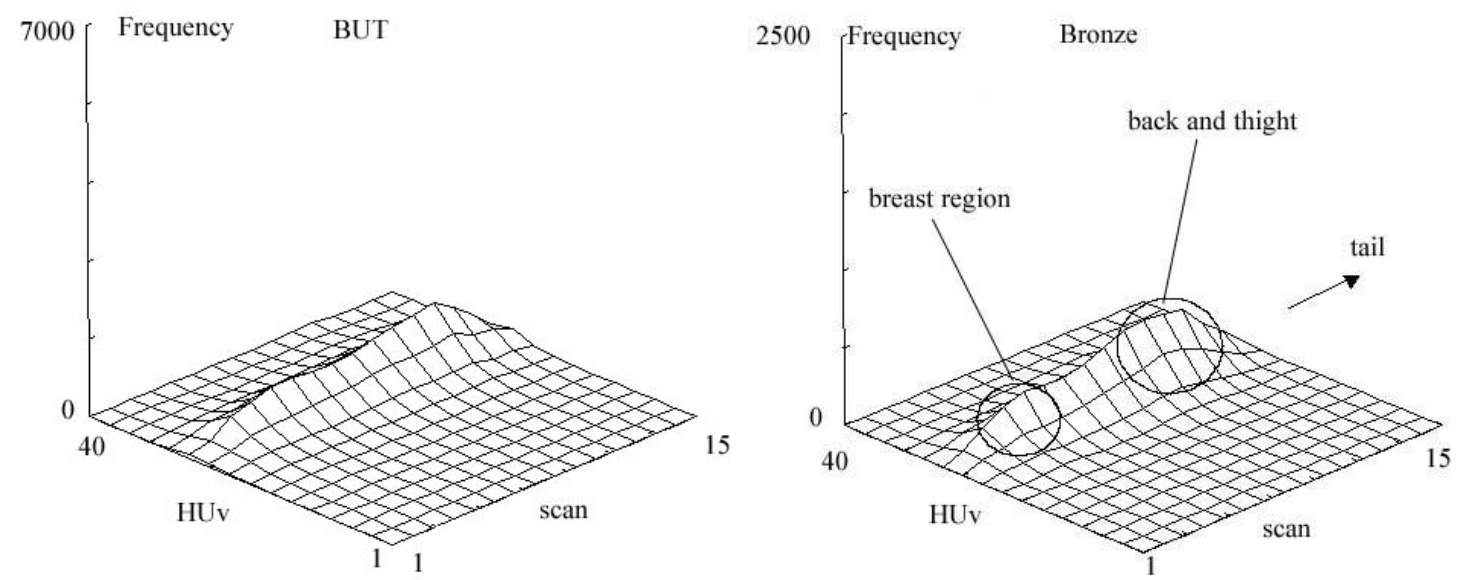

Fig. 3 and 4: 3D histograms at the age of 5 weeks in the BUT and Bronze genotypes

As females show a more intensive fat deposition, this process is demonstrated in this sex. Figures 3 and 4 are 3D histograms at the age of 5 weeks. Protrusions of the surface are characteristically located in the muscle density interval (HUv 21-30). At this age the caudal protrusion is more pronounced, indicating a higher allometric 
growth of the thighs in this early age, representing a higher proportion of the total muscle volume (PERÉNYI et al, 1980; SWATLAND, 1994).

At the age of 12 weeks (Figure 5 and 6) the two separate muscle protrusions show further development; the first (from scan 3 to 7) represents the breast region, while the caudal plots the thighs. The genotypes show marked differences at this age; in the BUT turkeys the proportion of the breast and wing muscles exceeds the back and the thighs. Compared to the Bronze turkeys, in the BUT birds the effects of the selection for early growth are clearly demonstrated. In this age category in the BUT birds besides the relatively low amount of cervical fat (scan 1) the deposition of the abdominal fat (scans 13-15) is plotted.
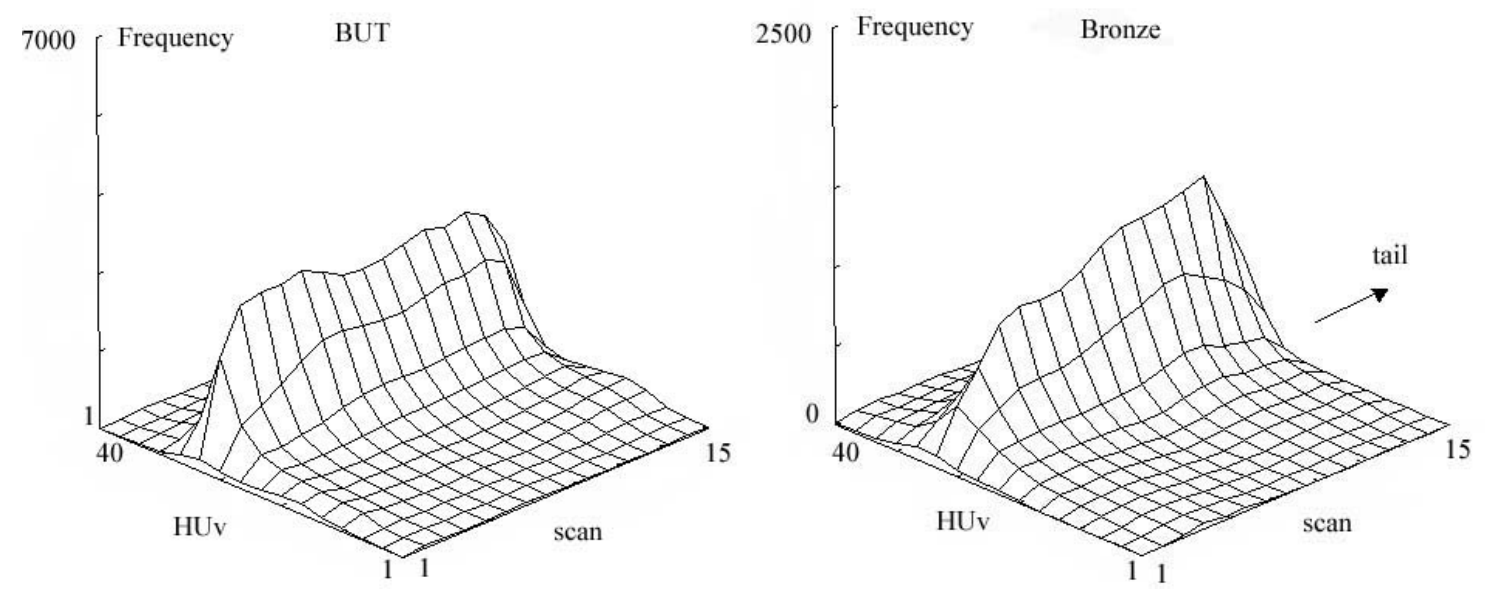

Fig. 5 and 6: 3D histograms at the age of 12 weeks in the BUT and Bronze genotypes

The further development of the tendencies described above can be clearly seen also at the age of 16 weeks (Fig. 7 and 8). Besides the intensive muscle tissue development the fat deposition becomes more strong, mainly in the BUT birds. The location of the abdominal fat depot extends, mainly cranially. The distribution of the muscles in the body show also increasing differences.
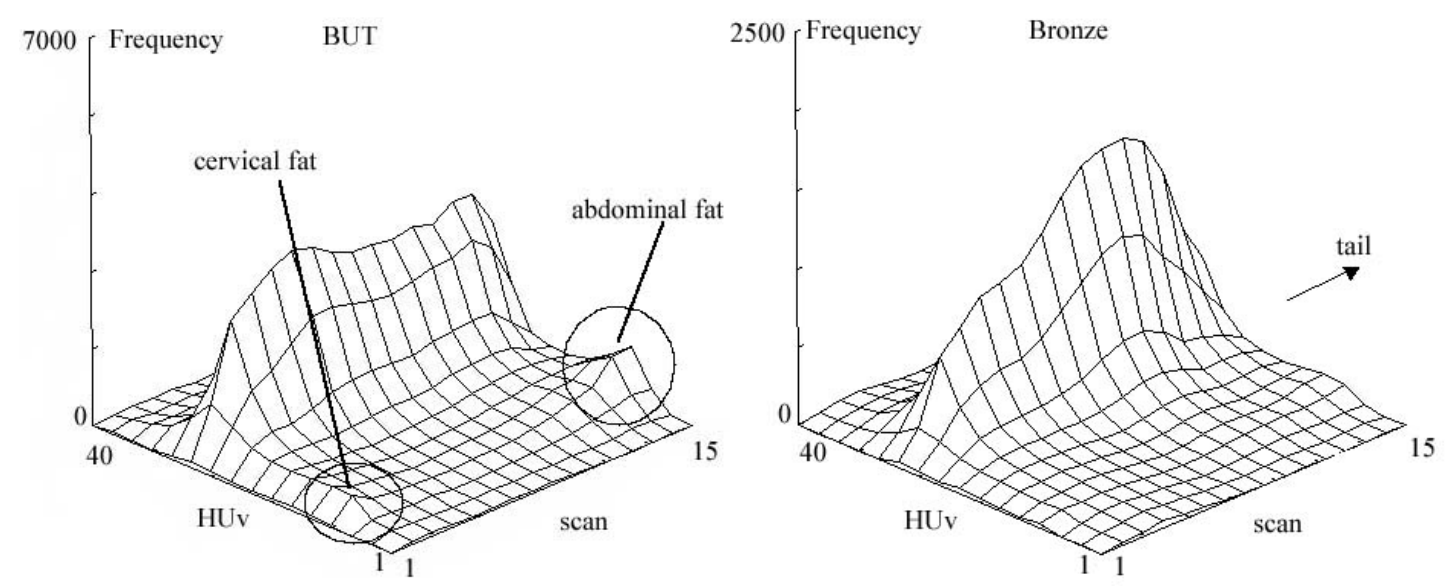

Fig. 7 and 8: 3D histograms at the age of 16 weeks in the BUT and Bronze genotypes

At the last examination the pronounced fat deposition in both genotypes is characteristic (Figure 9 and 10). Analysing the volumetric changes between weeks 16 and 21 it can be stated that the strongly increasing fat deposition, mainly in the Bronze 
turkeys, is compensated by the oppositely changing muscle development. The growth of the modern genotypes can be described as a measurably longer process. Regarding to MARUYAMA et al. (1993) the inflection points at which the maximum growth rate occured at the age of 112 days for body weight and 159 days for the breast muscle weight in Large White male hybrid turkeys. However, the back part and the thighs represent a much higher proportion in the total muscle volume in Bronze turkeys, indicating the effects of the selection work of the last 30 years.
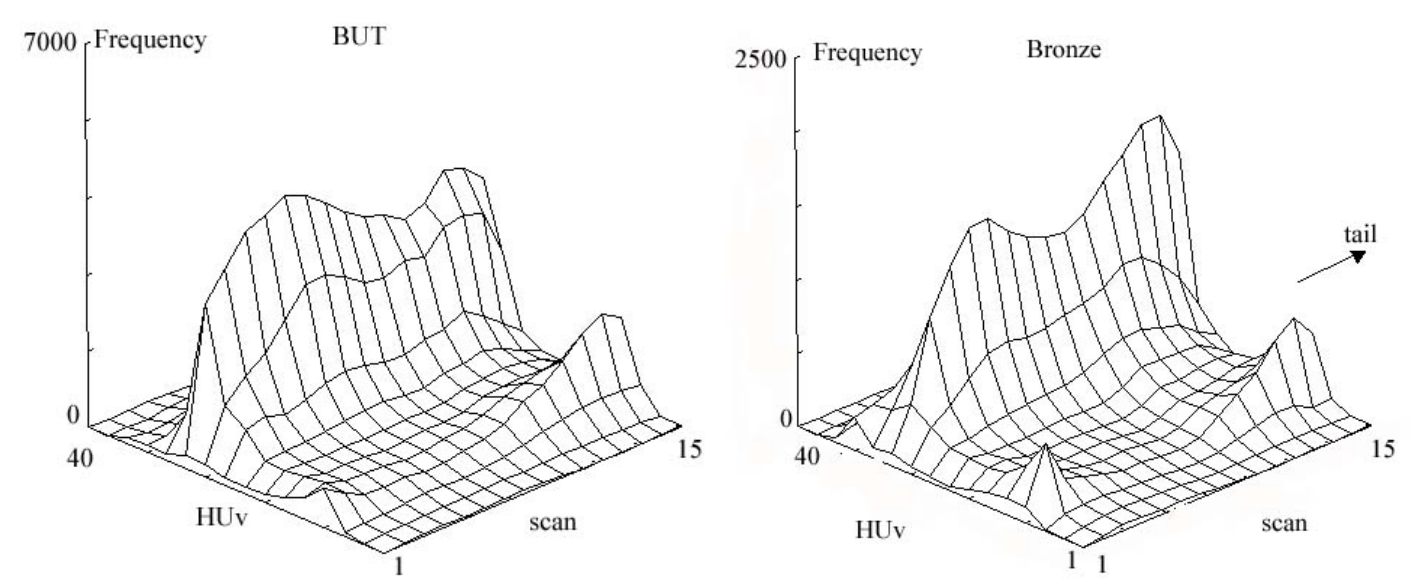

Fig. 9 and 10: 3D histograms at the age of 21 weeks in the BUT and Bronze genotypes

Applying the modern imaging and postprocessing facilities at the age of 21 weeks the morphologic comparison of the breast muscles was also carried out on 3D muscle reconstructions. The image postprocessing method is based on a relatively high number of scans at the body part of interest and gives a unique possibility for the judgement of the real morphological muscle properties. The three-dimensional reconstruction assessed from the sequencing of the images collected in a spiral scanning method is the only possibility for the real geometrical depiction and measurement of the different muscle groups (and also in the case of the thigh) in vivo. Figures 11 and 12 show the 3D reconstruction of breast muscle of the two genotypes. The shape of the sternum and the clavicle in the muscle is clearly to be recognize. The morphologic difference between the two muscles is definitely strong. The BUT sternum is longer, compared to the Bronze (18 and $15.6 \mathrm{~cm})$, however, this difference should be handled carefully due to the large differences in body weight. From a special aspect the findings of NESTOR et al. (2001) confirms these results, describing reciprocally crossed an experimental lines with sire lines of two commercial breeds to study the inheritance of carcass traits. One of the few traits that did not exibit a line difference was the keel length. When characterizing the difference, it can be stated that in the BUT genotype the muscle overlies, covers the sternum in a way. This turkey shows a twofold longer maximal breast muscle cross sectional surface width than the Bronze (21.6 and $10.6 \mathrm{~cm}^{2}$, respectively). This difference concerns mainly the $m$. pectoralis superficialis, possessing a measurably higher volume in the BUT turkey. Similar findings were taken by LILBURN and NESTOR (1991). Authors observed large differences within different lines of turkeys in the absolute and relative weight of $m$. pectoralis superficialis but not in $m$. pectoralis profundus. 

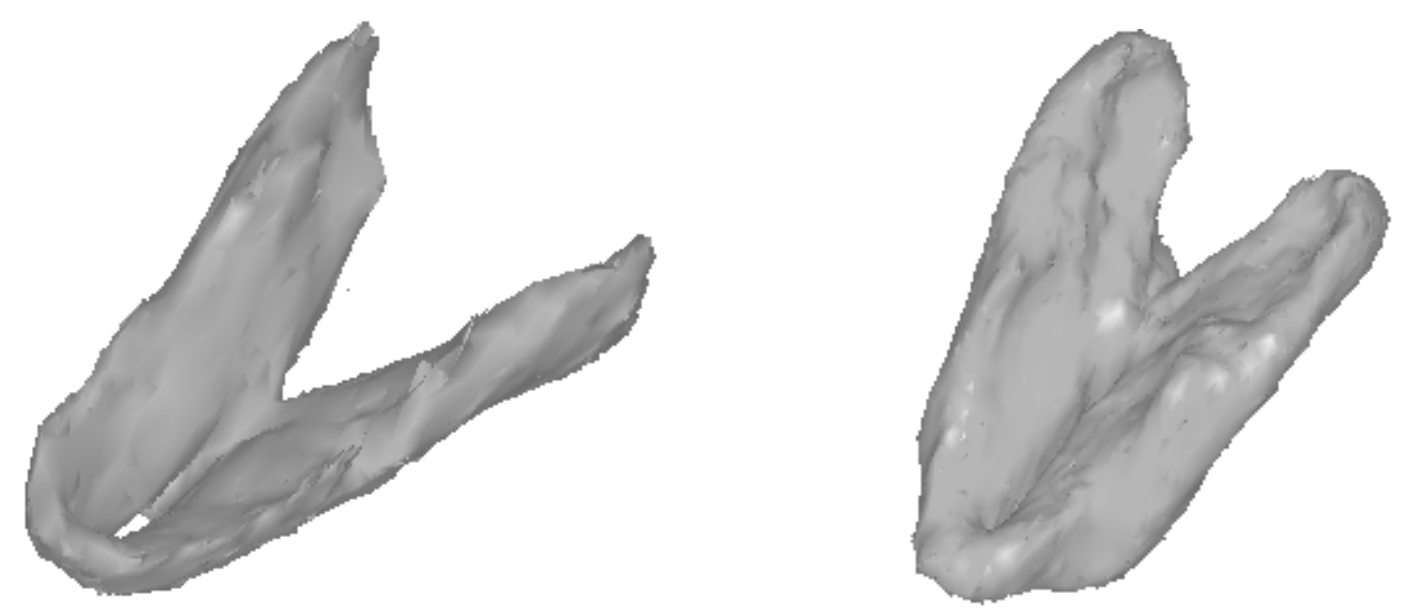

Fig. 11 and 12: The 3D reconstructed breast muscles of Bronze and BUT turkeys

\section{Conclusions}

In the intensive early growth phase of the turkeys a twofold difference was measured in the live weight of the two excessively divergent genotypes; in the muscle development a 3-4-fold difference was shown. Although with a decreasing tendency but in the interval of our experiment this trend continues, resulting in 3 to 5 -fold increase at the age of 21 weeks. The negative aspect matching the selection for meat production of the modern genotypes, namely the fat deposition starts earlyer, than in the Bronze turkeys, however, the predominant fat deposition was shown in the females of both genotypes. The results show a compensating trend in between fat deposition and muscle development within the $16^{\text {th }}$ and $21^{\text {st }}$ weeks. On the basis of the above data and method also allometric growth models can be developed, however a larger sample size is needed for it. To follow the tissue development the weekly repeated CT scanning procedure seems to be a suitable tool. The development of geometric models based on serial scans may help to characterize the breast muscle development in vivo, on the basis of 3-5 individual scans chosen. The method is furthermore suitable for the separate investigation of all recognizable organs or muscle groups.

\section{References}

Able Software 3D-DOCTOR 2.0 (1998-99)

BENTSEN, H.; SEHESTED, E.: Computerized tomography of chickens. Br. Poultry Sci., 30 (1989), 575-585

HAVENSTEIN, G.B.; TOELLE, V.D.; NESTOR, K.E.; BACON, W.L.:

Estimates of genetic parameters in turkeys. 2. Body weight and carcass characteristics. Poultry Science. 67 (1988), 1388-1399

HORN, P.; HERENDY, V.; KUSTOS ,O.; SÜTÖ, Z.:

Interactions between genotype, sex and nutrition in growth traits in turkeys. $2^{\text {nd }}$ Poultry Genetics Symposium (Gödöllö, 2001. 12-14 september) Proceedings 4-9

HORN, P.; SUTŐ̈, Z.; KUSTOSNÉ PÖCZE, O.; GYENIS, J.; MIHÓK,S.:

The effect of genetic and nutrition factors on meat production capacity of turkey. III. Int. Poultry Symp. Proc. (2000), 1-18

KÖVÉR, G.; ROMVÂRI, R.; HORN, P.; BERÉNYI, E.; JENSEN, J.F.; SORENSEN, P.:

In vivo assesment of breast muscle, abdominal fat and total fat volume in meat type chickens by magnetic resonance imaging. Acta Vet. Hung. 46 (1998), 135-144

LILBURN, M.S.; NESTOR, K.E.:

Body weight and carcass development in different lines of turkeys. Poultry Science, 70 (1991), 22232231

MARUYAMA ; KANEMAKI, N.; POTTS ,W.; MAJ, J.D.: 
Body and muscle growth of domestic turkeys (Melleagris gallopavo) and expression of myosin heavy chain isoforms in breast muscle. Growth Dev Aging, 57 (1993), 31-43

MITCHELL, A.D.; ROSEBROUGH, R.W.; CONWAY, J.M..:

Body composition analysis of chickens by dual energy x-ray absortiometry. Poultry Science, 76 (1997), 1746-1752

MITCHELL, A.D.; WANG,P.C,; ROSEBROUGH,R.W.; ELSASSER,T.H,; SCHMIDT,W.F.:

Assessment of body composition of poultry by nuclear magnetic resonance imaging and spectroscopy. Poultry Science. 70 (1991), 2494-2500

NESTOR, K.; ANDERSON, J.W.; VELLEMAN, S.G.:

Genetic variation in pure lines and crosses of large-bodied turkey lines. 2. Carcass traits and body shape. Poultry Science, 80 (2001), 1093-1104

NESTOR, K.; E.:

The influence of genetic increases in body weight on the abdominal fat pad of turkeys. Polutry Science $\mathbf{6 1}(1982), 2301-2304$

PERÉNYI, M.; SUUTÖ, Z.; UJVÁRINÉ, J.:

Changes in the proportion of the carcass parts of male and female heavy type turkeys between 4 and 20 ROMVÁRI, R.: weeks of age. Zootechnica International. No. 5 (1980), 39-40

Possibilities for computer tomography in the in vivo estimation of the body composition and slaughter value of meat rabbits and broiler chickens (in Hungarian), Ph.D. dissertation. Kaposvár, (1996), 121 pp.

ROMVÁRI, R.; ANDRÁSSY- BAKA, G.; REPA, I.; ZÁVODA, F.;SÜTÖ, Z.; HORN, P.: In vivo 3D evaluation of breast muscle of broiler chickens by means computer tomograph XXI World's Poultry congress, Montreal, 2000, August 20-24, Proc. CD 11-14

ROMVÁRI, R.; PERÉNYI, M.; HORN, P.: In vivo measurement of total body fat content of broiler chickens by X-ray computerised tomography. Znan. Prak. Poljopr. Tehnol., 24 (1994), 215-220

SCOLLAN, N.D.; CASTON, L.J.; LIU, Z.; ZUBAIR, A.K; LEESON, S.; MCBRIDGE, B.W.: Nuclear magnetic resonance imaging as a tool to estimate the mass of the pectoral muscle of chickens in vivo. Br. Poultry Science 39 (1998), 221-224

SÜTÖ, Z.;HORN, P.; KUSTOSNÉ PÖCZE, O.; HERENDY, V.; GYENIS, J.; MIHÓK, S.:

Effect of genetic and nutrition conditions on the meat production of turkeys. (in Hungarian), Baromfiágazat, I. (2001), 28-34

SVIHUS, B.; KATLE, J. :

Computerised tomography as a tool to predict composition traits in broilers. Comparisons of results across samples and years. Acta Agriculturae Scandinavia. Section A, Animal Science. 43 (1993), 214218

SWATLAND, H.J :

Structure and development of meat animals and poultry. Technomic Publ. AG., Basel. (1994), 610 pp.

Received: 2002-08-30

Accepted: 2003-04-29

Author's address

Ing. GABRIELLA ANDRÁSSY-BAKA, Dr. PhD RÓBERT ROMVÁRI,

Dr. PhD ZOLTÁN SÜTÖ, Ing. ANDRÁS SZABÓ, Prof. Dr. PETER HORN

Kaposvár University, Faculty of Animal Science

H-7400, Kaposvár, Guba S. U. 40.

Hungary 